\title{
Rind Stippling on Valencia Oranges by Copper Fungicides Used for Control of Citrus Black Spot in South Africa
}

\author{
G. C. Schutte, Senior Plant Pathologist, K. V. Beeton, Technical Assistant, Outspan Citrus Centre, P.O. Box 28, \\ Nelspruit 1200 South Africa; and J. M. Kotzé, University of Pretoria, Department of Microbiology and Plant \\ Pathology, Pretoria 0002 South Africa
}

\begin{abstract}
Schutte, G. C., Beeton, K. V., and Kotzé, J. M. 1997. Rind stippling on Valencia oranges by copper fungicides used for control of citrus black spot in South Africa. Plant Dis.81:851-854.

Four copper sprays and copper mixtures with dithiocarbamates aggravated stippling of the fruit rind of Valencia oranges if sprayed in succession at registered rates during the recommended protection period from October to January for control of citrus black spot in South Africa. Copper stippling was more severe on treatments in which copper oxychloride was sprayed in succession, individually, or in combination with mancozeb or maneb/ZnO. On the other hand, less copper stippling was observed on treatments in which three mancozeb applications were altered with a single copper oxychloride as tank mixtures with or without mancozeb, which was sprayed during midsummer (December and January). Cupric hydroxide resulted in more general copper stippling lesions than any other copper oxychloride spray program. Four successive applications of the wettable powder copper oxychloride formulation resulted in more copper stippling when compared with the suspension concentrate formulation. Stippling was calculated to be more severe with late applications of copper fungicides during December and January. In another experiment, all contact fungicides tested were effective in controlling citrus black spot.
\end{abstract}

Additional keyword: Guignardia citricarpa

Control of citrus black spot (CBS) disease, caused by Guignardia citricarpa Kiely, is entirely dependent on the application of fungicidal sprays during the critical period of infection from October to January (13, $15,18)$ in South Africa. When properly applied, fungicides such as copper afford excellent and inexpensive control and are used widely to control citrus diseases like CBS, scab, melanose, greasy spot, Phytophthora brown rot, Botrytis blight, Alternaria brown spot, mal secco, blast, and canker. Despite their efficacy and relatively low cost, however, copper fungicides are not popular among citrus growers because they darken blemishes caused by wind and certain insects and mites $(3,4,20$, 23,24). Concomitantly, repeated spray applications can result in toxic accumulation of copper in the soil at a low soil $\mathrm{pH}(1$, 6,19). Another side effect of copper fungicides is stippling of fruit tissue due to direct copper injury. This results in the formation of a black homogeneous mass of cells that separates the stipple from the healthy tissue by a definite phellogen layer, whereas darkening of blemishes due to cop-

Corresponding author: G. C. Schutte

E-mail: occnel@cis.co.za

Accepted for publication 21 March 1997.

Publication no. D-1997-0521-04R

(C) 1997 The American Phytopathological Society per appears as darkly stained flavedo tissue without the formation of a phellogen layer (5). These blemishes appear as darkly stained cells in the blemish area, and although copper is not directly phytotoxic to the fruit rind, it darkens the blemish, making the fruit appear unsightly and unacceptable for export (5). The current study was conducted to compare the effect of different copper fungicides and copper mixtures, with or without dithiocarbamates, on stippling and CBS control.

\section{MATERIALS AND METHODS}

Stippling of healthy rind. The side effects of different copper fungicides and spray programs consisting of copper oxychloride mixed with dithiocarbamates on rind stippling, as well as darkening of artificially wounded oranges caused by these different spray programs, were evaluated simultaneously in a single experiment. The experiment was conducted in a commercial Valencia orange (Citrus sinensis (L.) Osbeck) grove on rough lemon rootstock $(C$. jambhiri Lush.) at Crocodile Valley Estates near Nelspruit in the Eastern Transvaal, S.A., during 1993 and 1994. The trees were 45 years old, 3 to $4 \mathrm{~m}$ high, and planted on a 4 by $6 \mathrm{~m}$ spacing. The rows ran directly north to south.

Each treatment was replicated four times on two-tree plots arranged in a randomized complete-block design. Spray programs, dates, and rates of applications are listed in Table 1. The fungicides tested included copper oxychloride (Demildex, 85\% WP), copper oxychloride (50\% SC), cupric hydroxide (Kocide 101, 77\% WP), mancozeb (Dithane M-45, 80\% WP), and maneb/ZnO (Trimangol, 43,5/0,47\% SC). The fungicides were applied with a trailer-mounted, high-volume, high-pressure $(2,500$ to 3,000 $\mathrm{kPa}$ ) sprayer with two hand-held spray guns. Spray volumes varied according to the size and canopy density of the tree, but all trees were sprayed to the point of runoff, each receiving $\sim 35$ liters of spray mix per tree per application.

Copper stippling was rated on 100 fruits per tree, on a scale similar to that used previously (5): $0=$ no stippling; $1=$ faint stippling (on one-half of the fruit); $2=$ localized stippling (on three-quarters of the fruit); and $3=$ general stippling (on the whole fruit) (Fig. 1). This experiment also was evaluated at fruit maturity during June. Data were analyzed by analysis of variance (ANOVA), using Fisher's least significant difference (LSD) test $(P=0.05)$.

To determine which spray period(s) contributed substantially to stippling, results of all 15 treatments from Table 1 were combined, and the means were calculated. The four spray intervals (October, November, December, and January) were analyzed statistically according to Kruskal-Wallis ANOVA, followed by a nonparametric multiple comparison $(\alpha=0.05)(21)$.

Copper residue analysis was done at Outspan Laboratories in Pretoria, S.A. After harvest, external residues were removed immediately from the rind by dip washing whole fruit from the individual treatments with $250 \mathrm{ml}$ of $0.1 \mathrm{~N}$ acetic acid. To determine copper residues in the rind of individual treatments, the washed fruit was peeled, the rind was blended, and $2 \mathrm{~g}$ fresh weight was dried in an oven for $3 \mathrm{~h}$ at $500^{\circ} \mathrm{C}$. Each dried sample was dissolved in $6 \mathrm{~N}$ hydrochloric acid plus $6 \mathrm{~N}$ nitric acid and increased to $100 \mathrm{ml}$ with acetic acid. Copper residues (milligrams per kilogram) were determined with an atomic absorption meter (Spectra 250+, Varian, Melbourne, Australia).

Evaluation of copper and dithiocarbamate fungicides for CBS control. Due to the low CBS inoculum pressure in the orchard at Crocodile Valley Estates, Nelspruit, S.A, Valencia orange trees $(C$. sinensis) on rough lemon rootstock (C. jambhiri) in a commercial grove at Malelane Estates near Malelane in the Eastern Transvaal, S.A., 
were used to determine the efficacy of various copper and dithiocarbamate fungicides on CBS. These trees were 30 years old, 4 to $6 \mathrm{~m}$ high, and planted on a 4 by $7 \mathrm{~m}$ spacing. The rows ran directly north to south.

A randomized complete-block design with five two-tree plots was used per treatment. All treatments commenced during midOctober, with three follow-up treatments sprayed at monthly intervals from November to January. The fungicide rates evaluated are listed in Table 2. At fruit maturity during June, CBS severity was rated on 100 fruits per tree according to a 3-point index that was described previously $(7,12)$ : $0=$ clean fruit with no CBS lesions; $1=$ one to three CBS lesions per fruit; and $2=$ four or more CBS lesions per fruit. Data were analyzed by ANOVA, using Fisher's LSD test $(P=0.05)$.

\section{RESULTS}

Stippling of healthy rind. Results showed that four successive copper oxychloride (wettable powder [WP]) spray treatments (treatments 1 to 5), with or without dithiocarbamates, caused severe copper stippling of the fruit rind. Residual copper concentrations from washed fruit varied between 3.87 and $5.25 \mathrm{mg} / \mathrm{kg}$ in the treatments, compared to $0.09 \mathrm{mg} / \mathrm{kg}$ in the control (Table 1 ). In the dry peel, the copper residue concentrations from these treatments varied between 31 and $60 \mathrm{mg} / \mathrm{kg}$ in the treatments, compared to $6 \mathrm{mg} / \mathrm{kg}$ in the control. Accumulation of copper resulted from frequent spraying of copper fungicides. Four cupric hydroxide applications produced significantly $(P=0.05)$ more general copper stippling lesions $(11 \%)$ than any other copper oxychloride spray program. Less general stippling occurred with four suc- cessive copper oxychloride (WP) applications in tank mixtures with mancozeb and maneb/ZnO. Both copper oxychloride and cupric hydroxide (spray programs 1 and 2) produced the least fruit with no copper stippling lesions, illustrating the risk of successive copper applications during fruit development.

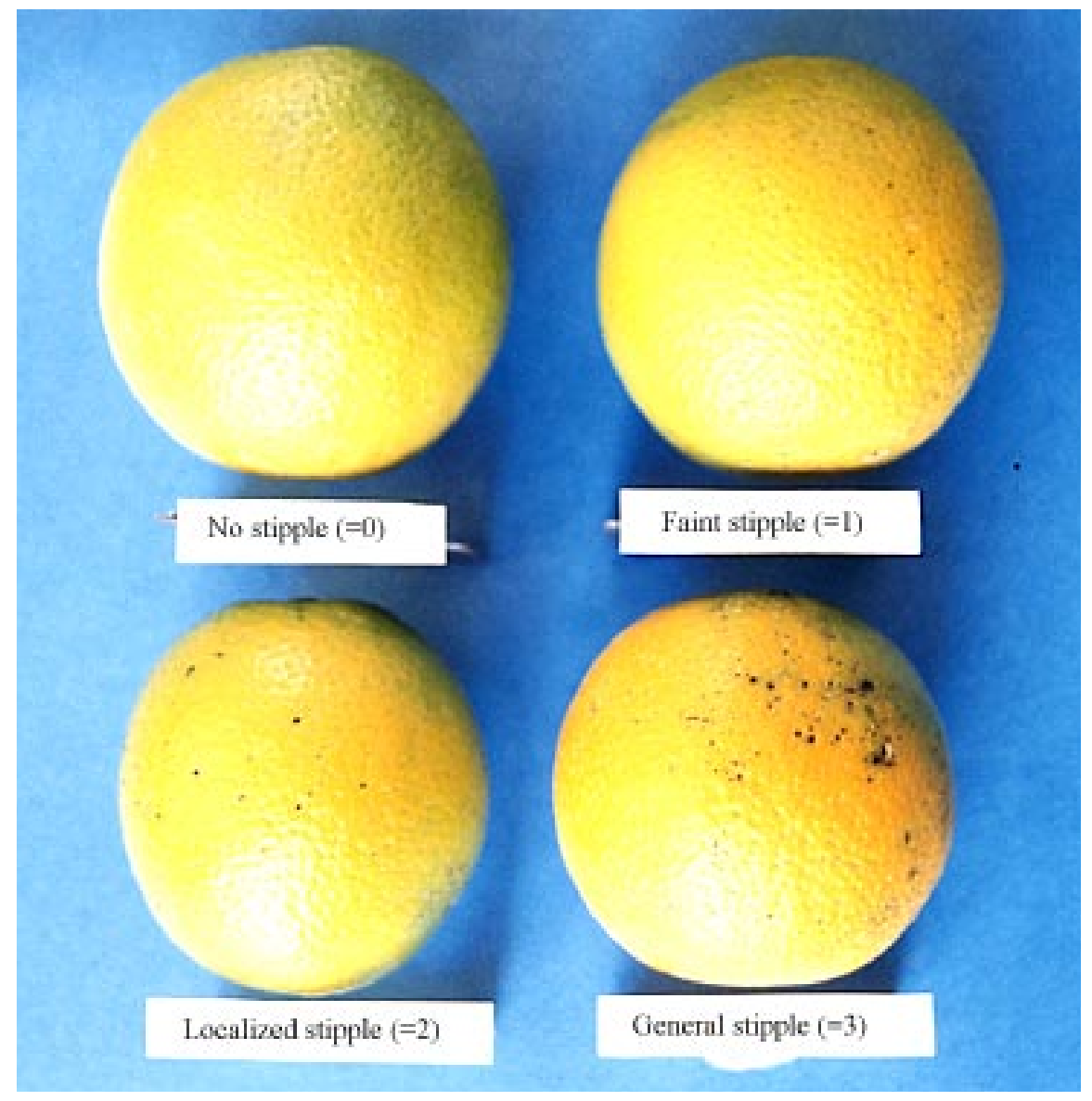

Fig. 1. Criteria used for evaluating stippling of Valencia oranges after application of different copper spray programs during the susceptible period from October to January for citrus black spot infection in South Africa.

Table 1. Effect of copper fungicides, dithiocarbamates, and combinations thereof applied as foliar sprays at different intervals to determine rind stippling of Valencia oranges at Crocodile Valley Estates, S.A., during 1993 and 1994

\begin{tabular}{|c|c|c|c|c|c|c|c|c|c|c|}
\hline \multirow{2}{*}{$\begin{array}{l}\text { Spray } \\
\text { program } \\
\text { no. }\end{array}$} & \multicolumn{4}{|c|}{ Spray date } & \multicolumn{2}{|c|}{ Copper residue (mg/kg) } & \multicolumn{4}{|c|}{ Copper stippling $(\%)^{\mathrm{v}}$} \\
\hline & 22 Oct. 1993 & 19 Nov. 1993 & 17 Dec. 1993 & 14 Jan. 1994 & $\begin{array}{l}\text { Washed from } \\
\text { fruit surface }\end{array}$ & $\begin{array}{c}\text { In dry } \\
\text { peel }\end{array}$ & None & Faint & Localized & General \\
\hline 1 & $\mathrm{CuOCI}(\mathrm{WP})^{\mathrm{w}}$ & $\mathrm{CuOCI}(\mathrm{WP})$ & $\mathrm{CuOCI}(\mathrm{WP})$ & $\mathrm{CuOCI}(\mathrm{WP})$ & 5.25 & 60 & $32.0 \mathrm{c}$ & $38.0 \mathrm{a}$ & $24.5 \mathrm{a}$ & $5.5 \mathrm{~b}$ \\
\hline 2 & $\mathrm{Cu}(\mathrm{OH})_{2}{ }^{\mathrm{x}}$ & $\mathrm{Cu}(\mathrm{OH})_{2}$ & $\mathrm{Cu}(\mathrm{OH})_{2}$ & $\mathrm{Cu}(\mathrm{OH})_{2}$ & 4.77 & 42 & $29.5 \mathrm{c}$ & $32.6 \mathrm{ab}$ & $27.0 \mathrm{a}$ & $11.0 \mathrm{a}$ \\
\hline 3 & $\mathrm{CuOCI}(\mathrm{SC})$ & $\mathrm{CuOCI}(\mathrm{SC})$ & $\mathrm{CuOCI}(\mathrm{SC})$ & $\mathrm{CuOCI}(\mathrm{SC})$ & 5.08 & 40 & $54.0 \mathrm{~b}$ & $26.5 \mathrm{bc}$ & $17.5 \mathrm{~b}$ & $2.0 \mathrm{c}$ \\
\hline 4 & $\mathrm{CuOCI}(\mathrm{WP})+\mathrm{M}^{\mathrm{y}}$ & $\begin{array}{l}\mathrm{CuOCI}(\mathrm{WP})+ \\
\mathrm{M}\end{array}$ & $\mathrm{CuOCI}(\mathrm{WP})+\mathrm{M}$ & $\mathrm{CuOCI}(\mathrm{WP})+\mathrm{M}$ & 4.14 & 31 & $60.5 \mathrm{~b}$ & $21.5 \mathrm{c}$ & $16.5 \mathrm{~b}$ & $1.5 \mathrm{c}$ \\
\hline 5 & $\mathrm{CuOCI}(\mathrm{WP})+\mathrm{T}^{\mathrm{z}}$ & $\mathrm{CuOCI}(\mathrm{WP})+\mathrm{T}$ & $\mathrm{CuOCI}(\mathrm{WP})+\mathrm{T}$ & $\mathrm{CuOCI}(\mathrm{WP})+\mathrm{T}$ & 3.87 & 42 & $53.0 \mathrm{~b}$ & $30.5 \mathrm{~b}$ & $14.0 \mathrm{~b}$ & $2.5 \mathrm{~b}$ \\
\hline 6 & CuOCI(WP) & M & M & M & 0.24 & 13 & $100 \mathrm{a}$ & $0 \mathrm{~d}$ & $0 \mathrm{c}$ & $0 \mathrm{c}$ \\
\hline 7 & M & $\mathrm{CuOCI}(\mathrm{WP})$ & M & M & 0.51 & 18 & $97.5 \mathrm{a}$ & $1.5 \mathrm{~d}$ & $1.0 \mathrm{c}$ & $0 \mathrm{c}$ \\
\hline 8 & $\mathrm{M}$ & M & CuOCI(WP) & M & 0.76 & 22 & $93.0 \mathrm{a}$ & $5.5 \mathrm{~d}$ & $1.5 \mathrm{c}$ & $0 \mathrm{c}$ \\
\hline 9 & M & M & M & $\mathrm{CuOCI}(\mathrm{WP})$ & 3.04 & 21 & $92.0 \mathrm{a}$ & $6.0 \mathrm{~d}$ & $2.0 \mathrm{c}$ & $0 \mathrm{c}$ \\
\hline 10 & M & M & M & M & 0.14 & 7 & $100 \mathrm{a}$ & $0 \mathrm{~d}$ & $0 \mathrm{c}$ & $0 \mathrm{c}$ \\
\hline 11 & $\mathrm{CuOCI}(\mathrm{WP})+\mathrm{M}$ & M & M & M & 0.11 & 12 & $100 \mathrm{a}$ & $0 \mathrm{~d}$ & $0 \mathrm{c}$ & $0 \mathrm{c}$ \\
\hline 12 & M & $\begin{array}{l}\mathrm{CuOCI}(\mathrm{WP})+ \\
\mathrm{M}\end{array}$ & M & M & 0.30 & 19 & $98.5 \mathrm{a}$ & $1.5 \mathrm{~d}$ & $0 \mathrm{c}$ & $0 \mathrm{c}$ \\
\hline 13 & M & M & $\mathrm{CuOCI}(\mathrm{WP})+\mathrm{M}$ & M & 0.77 & 18 & $100 \mathrm{a}$ & $0 \mathrm{~d}$ & $0 \mathrm{c}$ & $0 \mathrm{c}$ \\
\hline 14 & $\mathrm{M}$ & $\mathrm{M}$ & M & $\mathrm{CuOCI}(\mathrm{WP})+\mathrm{M}$ & 1.92 & 25 & $97.0 \mathrm{a}$ & $2.5 \mathrm{~d}$ & $0.5 \mathrm{c}$ & $0 \mathrm{c}$ \\
\hline 15 & Control & Control & Control & Control & 0.09 & 6 & $100 \mathrm{a}$ & $0 \mathrm{~d}$ & $0 \mathrm{c}$ & $0 \mathrm{c}$ \\
\hline
\end{tabular}

${ }^{v}$ Means in a column, based on four replicates, followed by the same letter are not significantly different $(P=0.05)$ according to Fisher's least significant difference test.

${ }^{\mathrm{w}} \mathrm{CuOCI}=$ copper oxychloride (applied at $1.70 \mathrm{~g}$ a.i./liter of water) wettable powder/suspension concentration (WP/SC).

${ }^{x} \mathrm{Cu}(\mathrm{OH})_{2}=$ cupric hydroxide (applied at $1.50 \mathrm{~g}$ a.i./liter of water) WP.

${ }^{\mathrm{y}} \mathrm{M}=$ mancozeb (applied at $1.60 \mathrm{~g}$ a.i./liter of water) WP.

${ }^{\mathrm{z}} \mathrm{T}=$ maneb/ZnO (applied at $0.80 \mathrm{~g}$ a.i./liter of water) SC. 
The type of copper formulation also had an effect on stippling. Here, the WP formulation of copper oxychloride (treatment 1) caused significantly $(P=0.05)$ more copper stippling of the fruit rind (based on the criteria used in evaluation) when compared with the copper oxychloride suspension concentrate (SC) formulation (treatment 3). On the other hand, both treatments had the same amount of copper residues washed from the fruit surface $(5.25$ and $5.08 \mathrm{mg} / \mathrm{kg}$, respectively) (Table 1). With regard to the amount of copper residues in the orange peel, the WP formulation of copper oxychloride had the highest copper concentration $(60 \mathrm{mg} / \mathrm{kg})$ of all the treatments tested.

Concomitantly, mixtures of maneb and mancozeb with copper oxychloride (WP) (treatments 4 and 5) caused significantly less copper stippling (53 and 60.5\%, respectively) than the copper oxychloride treatment (treatment 1), under which $32 \%$ of the fruit had no stippling based on all criteria used for evaluation. The inclusion of a single copper oxychloride (WP) spray alone (treatments 6 to 9) or copper oxychloride in tank mixtures with mancozeb (treatments 11 to 14), altered on a monthly basis in the mancozeb spray program, resulted in more copper stippling with the late application (January) of these copper oxychloride (WP) treatments (Table 1). However, these spray programs were not significantly different from each other $(P=$ $0.05)$ based on all criteria used for stippling evaluation. Copper residues were higher in the treatments applied later during the summer (treatments 6 to 9 and 11 to 14). A comparison of the latter treatments indicates that mixtures of mancozeb with copper oxychloride resulted in less copper residues washed from fruit surfaces. The mancozeb spray program (treatment 10) resulted in no copper stippling (Table 1). Stippling was calculated to be more severe with plied during December and January (Table 3).

Evaluation of copper and dithiocarbamate fungicides for CBS control. Significant differences in percent clean fruit late copper fungicide sprays that were ap-
$(P=0.05)$ were achieved only between mancozeb and mancozeb plus copper oxychloride (WP) treatments (sprayed at combined rates of 0.80 and $0.85 \mathrm{~g}$ a.i./liter of water, respectively) (Table 2). No significant differences were observed between any of the treatments with regard to the rejected-fruit category. The control, on the other hand, was significantly different from all other treatments (Table 2).

\section{DISCUSSION}

Successive application of copper fungicides, as registered for CBS control in South Africa, were phytotoxic and caused stippling. This finding supports a previous report (5) that showed that four cuprous oxide treatments sprayed at 2-week intervals during November and December also resulted in copper stippling but that less stippling was recorded with early applications of cuprous oxide during October. However, cuprous oxide was not included as a late application during January (5), which is required to prevent CBS infection during the critical infection period from October to January $(15,18,19)$. We suggest that stippling may be due to the abundance of polyphenol oxidases in citrus fruit during midsummer, because polyphenol oxidants act only with copper to cause darkening of blemishes (17). It also was reported that the phytotoxic effect due to copper is most common when copper is applied at high temperatures during summer (22).

Although not tested, it could be that total copper has little relationship with stippling and that it could be related to available ionic copper. The theory that the inclusion of mancozeb with copper oxychloride should increase ionic copper was shown in this study to be inaccurate because this mixture actually resulted in less stippling. Previous research $(2,11)$ showed that the toxicity of a copper-mancozeb combination does not appear to be a result of increased soluble copper or ionic copper in solution but may be due to a synergistic interaction between copper and mancozeb. Therefore, the selection of combinations of copper fungi- cides and dithiocarbamates does not appear to require increased copper solubility, but it appears to be important for copper to reside on the fruit surface for an extended period, which in this study resulted in less stippling and no reduction in CBS control.

Stippling of the fruit rind was linked to frequent copper fungicide applications, especially when applied later in the growing season. Similar effects also were found in Florida, where copper was applied late in the season for melanose control, resulting in the formation of corky lesions and excessive blackening of fruit blemishes (810,14,19). It was reported that darkening of existing blemishes appeared as darkly stained cells in the blemish area, which is not directly phytotoxic to the fruit rind but which darkens the blemish, making the fruit appear unsightly and unacceptable for export (5).

Growers have to consider several factors when choosing copper fungicides. The cost and type of copper formulation is of primary consideration, followed by efficacy of the chosen product against the target organism. Although this study showed that the SC formulation of copper oxychloride resulted in less copper stippling than the WP formulation of the same fungicide, they are not highly effective and are much more expensive to manufacture (22). Liquid copper fungicides other than copper oxychloride, such as copper ammonium carbonate and copper rosin, are liable to cause stomatal necrosis, more so if spray oil is added to the spray mixture (24).

Four successive applications of mancozeb mixtures with copper fungicides resulted in acceptable CBS control. This is promising because worldwide controversy regarding the possible carcinogenic effect of ethylene thiourea (ETU) (a common degradation product of dithiocarbamates) in food stuffs has led to research aimed at eliminating ETUs. When mancozeb is mixed with copper oxychloride, this mixture has a stabilizing effect on the degradation of mancozeb to ETU and, subsequently, can be used to suppress ETU generation in commercial products (16). Although frequent spraying of copper fungicides is effective for CBS control, side effects such as stippling and

Table 3. Mean percentage ( \pm 1 standard error) of Valencia oranges with darkening of artificial blemishes after copper fungicides were applied at different times in spray programs to control citrus black spot ${ }^{y}$

Table 2. Evaluation of copper and dithiocarbamate fungicides sprayed during the susceptible period from October to January for citrus black spot (CBS) control on Valencia oranges at Malelane Estates, S.A., during 1993 and 1994

\begin{tabular}{|c|c|c|c|c|c|}
\hline \multirow[b]{2}{*}{ Treatment $^{\mathbf{y}}$} & \multirow[b]{2}{*}{$\begin{array}{l}\text { Concentration } \\
\text { (g a.i./L of water) }\end{array}$} & \multirow[b]{2}{*}{$\begin{array}{c}\text { No. of } \\
\text { applications }\end{array}$} & \multicolumn{3}{|c|}{ No. of CBS lesions on fruitz } \\
\hline & & & $\begin{array}{c}\text { No lesions } \\
(\%)\end{array}$ & $\begin{array}{c}\text { 1-3 lesions } \\
(\%)\end{array}$ & $\begin{array}{l}4 \text { or more } \\
\text { lesions }(\%)\end{array}$ \\
\hline Mancozeb & 1.60 & 4 & $97.3 \mathrm{a}$ & $1.2 \mathrm{a}$ & $1.5 \mathrm{a}$ \\
\hline Cupric hydroxide & 1.54 & 4 & $94.3 \mathrm{ab}$ & $4.5 \mathrm{ab}$ & $1.2 \mathrm{a}$ \\
\hline Copper oxychloride & 1.70 & 4 & $93.6 \mathrm{ab}$ & $5.2 \mathrm{~b}$ & $1.2 \mathrm{a}$ \\
\hline $\begin{array}{l}\text { Mancozeb + copper } \\
\text { oxychloride }\end{array}$ & $1.20+1.28$ & 4 & $93.3 \mathrm{ab}$ & $5.2 \mathrm{~b}$ & $1.5 \mathrm{a}$ \\
\hline $\begin{array}{l}\text { Mancozeb + copper } \\
\text { oxychloride }\end{array}$ & $0.80+0.85$ & 4 & $92.0 \mathrm{~b}$ & $4.5 \mathrm{ab}$ & $3.5 \mathrm{a}$ \\
\hline Control & $\ldots$ & $\ldots$ & $55.8 \mathrm{c}$ & $18.6 \mathrm{c}$ & $25.6 \mathrm{~b}$ \\
\hline
\end{tabular}

y Fungicide formulations: mancozeb (Dithane M-45, 80\% WP), copper oxychloride (Demildex , 85\% WP), and cupric hydroxide (Kocide 101, 77\% WP).

${ }^{\mathrm{z}}$ Means in a column, based on five replicates, followed by the same letter are not significantly different $(P=0.05)$ according to Fisher's least significant difference test.

\begin{tabular}{lc}
\hline $\begin{array}{l}\text { Spray } \\
\text { time }\end{array}$ & $\begin{array}{c}\text { Mean percentage of fruit } \\
\text { with darkened blemish }\end{array}$ \\
\hline October & $17.1 \pm 5.20 \mathrm{a}$ \\
November & $30.9 \pm 5.48 \mathrm{ab}$ \\
December & $72.3 \pm 9.92 \mathrm{bc}$ \\
January & $99.4 \pm 0.60 \mathrm{c}$ \\
\hline
\end{tabular}

y Table 1 describes the treatments (1 to 15$)$ used.

${ }^{z}$ Common letters indicate no significant difference according to Kruskal-Wallis analysis of variance followed by a nonparametric multiple comparison $(\alpha=0.05)$. 
darkening of blemishes make them unsuitable for spraying during December and January.

\section{ACKNOWLEDGMENTS}

We thank D. Solomon, Crocodile Valley Estates, S.A., and H. Botes, Malelane Estates, S.A., for the use of their land for plot work.

\section{LITERATURE CITED}

1. Alva, A. K., Graham, J. H., and Tucker, D. P. 1993. Role of calcium in the amelioration of copper phytotoxicity for citrus. Soil Sci. 155: 211-218.

2. Bonn, W. G., and Lesage, S. 1984. Control of bacterial speck of tomato by copper and ethylenebisdithiocarbamate fungicides: Their efficacy and residues on leaves. J. Environ. Sci. Health 19:29-38.

3. Brodrick, H. T. 1970. Investigations into blemishes on citrus fruits. I. The effects of wind, thrips and red mite. S. Afr. Citrus J. 441: $7,9,11$.

4. Brodrick, H. T. 1970. Investigations into blemishes on citrus fruits. II. The effects of wind at various stages of development. S. Afr. Citrus J. 441:13,15,17,25.

5. Brodrick, H. T. 1970. Investigations into blemishes on citrus fruits. IV. Accentuation of blemish marks by copper fungicide sprays. $\mathrm{S}$. Afr. Citrus J. 441:27-29,31.

6. Chapman, H. D., Bradford, G. R., and Rayner, D. S. 1969. Copper toxicity: Effect on orange yields. Calif. Citrogr. 54:131,154-156.
7. De Wet, T. H. 1987. Control of citrus black spot, Lisbon Estate with particular reference to resistance of Guignardia citricarpa Kiely to benomyl. M.Sc. (Agric.) thesis. University of Pretoria, Pretoria, S.A.

8. Freeman, B. 1976. Rind blemish of citrus. I. Initiation and development. Sci. Hortic. 4:317327.

9. Freeman, B. 1976. Rind blemish of citrus. II. Structure and ultrastructure. Sci. Hortic. 4:329336.

10. Grierson, W. 1958. Causes of low pack-outs in Florida packing houses. Fla. State Hortic. Soc. 71:166-170.

11. Jones, J. B., Woltz, S. S., Jones, J. P., and Portier, K. L. 1991. Population dynamics of Xanthomonas campestris pv. vesicatoria on tomato leaflets treated with copper bactericides. Phytopathology 81:714-719.

12. Kellerman, C. R. 1976. Korrektiewe beheer van swartvleksiekte by sitrus. M.Sc. (Agric.) thesis. University of Pretoria, Pretoria, S.A.

13. Kellerman, C. R., and Kotzé, J. M. 1977. The black spot disease of citrus and its control in South Africa. Proc. Int. Soc. Citricult. 3:992-996.

14. Knorr, L. C., Suit, R. F., and Du Charme, E. P. 1957. Handbook of citrus diseases in Florida. Univ. Fla. Bull. 587.

15. Kotzé, J. M. 1963. Studies on the black spot disease of citrus caused by Guignardia citricarpa Kiely, with particular reference to its epiphytology and control at Letaba. D.Sc. (Agric.) thesis. University of Pretoria, Pretoria, S.A.
16. Lo, C. C., and Ho, M. H. 1993. Determination of imidazolidine-2-thione (ethylene thiourea) in ethylene bisdithiocarbamate formulations. Pestic. Sci. 37:247-251.

17. Mayer, A. M., and Hard, E. 1979. Polyphenol oxidases in plants. Phytochem. 18:193-215.

18. McOnie, K. C. 1964. Orchard development and discharge of ascospores of Guignardia citricarpa and the onset of infection in relation to the control of citrus black spot. Phytopathology 54:1448-1453.

19. McOnie, K. C., and Smith, J. H. 1964. Dithiocarbamates versus copper fungicides for the control of black spot disease. S. Afr. Citrus J. 367:13-19.

20. Pratt, R. M. 1958. Florida guide to citrus insects, diseases and natural disorders in color. University of Florida, Agricultural Experiment Station, Gainesville.

21. Siegel, S., and Castellan, N. J. 1989. Nonparametric Statistics for the Behavioural Sciences. 2nd ed. McGraw-Hall, Singapore.

22. Timmer, L. W., and Zitko, S. E. 1996. Evaluation of copper fungicides and rates of metallic copper for control of melanose on grapefruit in Florida. Plant Dis. 80:166-169.

23. Whiteside, J. O. 1983. Current and potential use of disease-control chemicals on citrus trees. Plant Dis. 67:244.

24. Whiteside, J. O. 1988. Pesticide spray injuries. Page 62 in: Compendium of Citrus Diseases. J. O. Whiteside, S. M. Garsney, and L. W. Timmer, eds. The American Phytopathological Society, St. Paul, MN. 